\title{
ASAS ASAS BERACARA DI PENGADILAN TATA USAHA NEGARA
}

\author{
Nama Mahasiswa : MONICA REFALS \\ Email: MONICAREFALS9898@GMAI.COM \\ No BP: 1710003600441 \\ Perguruan Tinggi : UNIVERSITAS EKA SAKTI PADANG
}

\section{A. PENDAHULUAN}

Pasal 4 Undang-Undang Republik Indonesia Nomor 9 Tahun 2004 Peradilan TUN Mengatur Bahwa Peradilan Tata Usaha Negara Adalah Salah Satu Pelaku kekuasaan kehakiman bagi rakyat pencari keadilan terhadap sengketa tata usaha negara. Pasal 5 ayat (1) dan ayat (2) serta Pasal 6 Undang-Undang Republik Indonesia Nomor 5 Tahun 1986 Peradilan Tun, pada pokoknya mengatur bahwa kekuasaan kehakiman di lingkungan Peradilan Tata Usaha Negara dilaksanakan oleh Pengadilan Tata Usaha Negara dan Pengadilan Tinggi Tata Usaha Negara dan berpuncak pada Mahkamah Agung sebangai Pengadilan Negara Tertinggi. Pengadilan Tata Usaha Negara berkedudukan di ibu kota Kabupaten/Kota, dan daerah hukumnya meliputi wilayah kabupaten/kota. Sedangkan Pengadilan Tinggi Tata Usaha Negara berkedudukan di Ibu kota Provinsi, dan daerah hukumnya meliputi wilayah Provinsi. Namun demikan sampai dengan saat Pengadilan TUN belum terbentuk di tiap ibu kota Kabupaten/Kota, dan Pengadilan Tinggi TUN juga belum terbentuk di tiap Ibu Kota Propinsi. Bahwa Pengadilan TUN tingkat pertama maupun tingkat banding mengadili Sengketa TUN. Menurut Pasal 1 angka 10 Uu Undang-Undang Republik Indonesia Nomor 51 Tahun 2009 Peradilan TUN, Sengketa TUN adalah sengketa yang timbul dalam bidang TUN antara orang atau badan hukum perdata dengan badan atau pejabat TUN baik di tingkat pusat maupun di daerah, sebagai akibat dikeluarkannya keputusan TUN termasuk sengketa kepegawaian berdasarkan peraturan perundang-undangan yang berlaku. Dengan demikian pengertian hukum acara peradilan TUN adalah hukum yang mengatur tentang cara menyelesaikan Sengketa TUN antara orang atau badan hukum perdata dengan badan atau pejabat TUN akibat dikeluarkannya keputusan TUN termasuk sengketa kepegawaian berdasarkan peraturan perundang - undangan yang berlaku. Hukum Acara Peradilan TUN termuat dalam UU Peradilan TUN, karena UU Peradilan TUN selain memuat aturan hukum tentang lembaga Peradilan TUN juga memuat tentang hukum acara yang berlaku dalam Peradilan TUN. Di bidang perdata dan tata usaha negara, Kejaksaan dengan kuasa khusus dapat bertindak baik di dalam maupun di luar pengadilan untuk dan atas nama negara atau pemerintah (vide Pasal 30 ayat (2) Undang-undang Nomor 16 Tahun 2004 tentang Kejaksaan RI). Selain itu Kejaksaan juga dapat memberikan pertimbangan dalam bidang hukum kepada instansi pemerintah lainnya (vide Pasal 34 UU Nomor 16 Tahun 2004). Jaksa Agung Muda Perdata dan Tata Usaha Negara (JAM DATUN) adalah unsur pembantu pimpinan dalam melaksanakan tugas dan wewenang Kejaksaan di bidang perdata dan tata usaha negara (vide Pasal 23 ayat (1) dan Pasal 24 ayat (1) Peraturan Presiden (Perpres) Nomor 38 Tahun 2010 tentang Organisasi dan Tata Kerja Kejaksaan RI sebagaimana diubah dengan Perpres Nomor 29 Tahun 2016). Salah satu tugas dan fungsi dari JAM DATUN adalah mewakili negara dan pemerintah dalam hal ini badan atau pejabat tata usaha negara di dalam dan di luar pengadilan tata usaha negara dalam rangka menjaga kewibawaan negara/pemerintah. Tugas dan fungsi ini dilaksanakan oleh Direktorat Tata Usaha Negara pada JAM DATUN, Asisten Perdata dan Tata Usaha Negara cq Kepala Seksi Tata Usaha Negara untuk tingkat Kejaksaan Tinggi dan Kepala Seksi DATUN untuk tingkat Kejaksaan Negeri. Pendidikan dan Pelatihan Pembentukan Jaksa (PPPJ) dimaksudkan untuk menyiapkan jaksa-jaksa yang siap bertugas 
dalam rangka menjalankan tugas dan fungsi Kejaksaan RI, baik di bidang pidana, perdata dan TUN, dan tugas-tugas lainnya. Untuk melaksanakan tugas sebagai jaksa dengan baik perlu memiliki kompetensi dasar, demikian pula dengan seorang jaksa pengacara negara, perlu memiliki kompetensi dasar diantaranya adalah menguasai dan memahami hukum acara tata usaha negara untuk bertindak mewakili negara dan atau pemerintah di depan peradilan tata usaha negara. Dalam rangka mempersiapkan jaksa-jaksa yang sebagiannya nanti akan bertugas sebagai jaksa pengacara negara, di dalam PPPJ ini diberikan materi mengenai hukum acara tata Hukum Acara TUN 1Hukum Acara TUN 2 usaha negara, sehingga pada saatnya nanti para peserta PPPJ akan siap menghadapi tugas beracara di peradilan tata usaha negara, mulai dari tingkat pertama sampai tingkat kasasi, mulai dari menyusun surat jawaban sampai dengan menyusun memori kasasi atau bahkan memori peninjauan kembali. Untuk update informasi, di dalam modul ini juga akan dibahas mengenai ketentuanketentuan baru dalam hukum acara tata usaha negara antara lain permohonan untuk mendapatkan putusan dan/atau Tindakan Badan atau Pejabat Pemerintahan (positif fiktif) yang diatur dalam Peraturan Mahkamah Agung (PERMA) Nomor 5 Tahun 2015 tentang Pedoman Beracara Untuk Memperoleh Putusan Atas Penerimaan Permohonan Guna Mendapatkan Keputusan dan/atau Tindakan Badan atau Pejabat Pemerintahan. Selain itu juga akan dibahas kewenangan baru dari Pengadilan Tata Usaha Negara untuk memutus ada atau tidaknya unsur penyalahgunaan wewenang yang dilakukan oleh Badan dan/atau Pejabat Pemerintahan sebagaimana diatur dalam PERMA Nomor 4 Tahun 2015 tentang Pedoman Beracara Dalam Penilaian unsur Penyalahgunaan Wewenang.

\section{B. PEMBAHASAN}

Hukum acara yang digunakan pada Peradilan Tata Usaha Negara mempunyai persamaan dengan hukum acara yang digunakan pada Peradilan Umum untuk perkara perdata (Penjelasan Umum angka (5) Undang-Undang Nomor 5 Tahun 1986 tentang Peradilan Tata Usaha Negara), meskipun proses pemeriksaan di Peradilan Tata Usaha Negara memiliki kekhususan jika dibandingkan dengan pemeriksaan di Peradilan Umum untuk perkara perdata. Kekhususan hukum acara Peradilan Tata Usaha Negara menurut Hadjon1, terletak pada asas-asas yang melandasinya yaitu: a. Asas Praduga Rechmatig (vermoeden van rechmatigheid) : Asas ini mengandung makna bahwa setiap tindakan penguasa selalu harus dianggap sah/menurut hukum (rechmatig) sampai ada pembatalannya ; b. Asas Pembuktian Bebas : Hakim yang menetapkan beban pembuktian ; Sistem pembuktian mengarah kepada pembuktian bebas (vrijbewijs) yang terbatas. Menurut Pasal 107 UU Nomor 51 Tahun 2009 (UU Peradilan TUN hakim dapat menentukan apa yang harus dibuktikan, beban pembuktian, beserta penilaian pembuktian, tetapi Pasal 100 menentukan secara limitatif mengenai alat-alat bukti yang digunakan. c. Asas Keaktifan Hakim : Maksudnya adalah untuk menyeimbangkan kedudukan para pihak dalam sengketa yaitu Tergugat (Badan atau Pejabat Tata Usaha Negara) dan Penggugat (Orang atau Badan Hukum Perdata) ; Hakim berperan lebih aktif dalam proses persidangan, guna mencari kebenaran materiil. Keaktifan hakim dapat ditemukan antara lain dalam ketentuan Pasal 63 ayat (2) butir a dan b, Pasal 80, Pasal 85, Pasal103 ayat (1), Pasal 107 UU Nomor 51 Tahun 2009 (UU Peradilan TUN). Asas keaktifan hakim secara prinsip memberikan kewenangan yang luas kepada hakim Tata Usaha Negara dalam proses pemeriksaan sengketa tata usaha negara menyangkut pembagian beban pembuktian dan penentuan hal-hal yang harus dibuktikan. Konsekuensi dari keberadaan asas keaktifan hakim adalah dimungkinkannya penerapan asas ultra petita yang pertama kali dituangkan dalam Putusan MA Nomor : 5K/TUN/1992 tanggal 23 Mei 1991, yaitu tindakan hakim menyempurnakan atau melengkapi objek sengketa yang diajukan para pihak kepadanya. Lebih lanjut dengan mengutip van Buren, Marbun menyatakan bahwa Hakim 
administrasi diberikan peran aktif karena hakim tidak mungkin membiarkan dan mempertahankan tetap berlakunya suatu keputusan administrasi negara yang nyata keliru dan jelas bertentangan dengan undang-undang yang berlaku, hanya karena alasan para pihak tidak mempersoalkannya dalam objek sengketa. Sesuai dengan pasal 63 UU PTUN, sebelum dilakukan pemeriksaan terhadap pokok sengketa hakim mengadakan rapat permusyawaratan untuk menetapkan apakah gugatan dinyatakan tidak diterima atau tidak berdasar atau dilengkapi dengan pertimbangan (pasal 62 UU PTUN), dan pemeriksaan persiapan untuk mengetahui apakah gugatan penggugat kurang jelas, sehingga penggugat perlu untuk melengkapinya. Keaktifan hakim dimaksudkan untuk mengimbangi kedudukan para pihak yang tidak berimbang, sebagaimana inti dari pasal 58, 63, ayat (1) dan (2), Pasal 80 dan Pasal 85 UndangUndang Republik Indonesia Nomor 5 Tahun 1986 d. Asas Putusan Pengadilan mempunyai kekuatan mengikat (erga omnes) : Putusan Pengadilan Tata Usaha Negara mengikat secara publik, tidak hanya mengikat para pihak yang bersengketa saja. Hal ini sebagai konsekuensi sifat sengketa tata usaha negara yang merupakan sengketa hukum publik. e. Asas Gugatan Pada dasarnya tidak dapat menunda pelaksanaan KTUN yang dipersengketakan, kecuali ada kepentingan yang mendesak dari penggugat sebagaimana terdapat pada pasal 67ayat 1dan ayat 4 huruf a. f. Asas Kesatuan Beracara Adalah asas kesatuan beracara dalam perkara sejenis baik dalam pemeriksaan di peradilan judex facti, maupun kasasi dengan MA sebagai Puncaknya. g. Asas Penyelenggaraan Kekuasaan Kehakiman yang Merdeka dan Bebas Menurut Pasal b 24 UUD 1945 jo pasal 44 UU 14/1970, penyelenggaraan kekuasaan kehakiman yang merdeka dan bebas dari segala macam campur tangan kekuasaan yang lain baik secara langsung dan tidak langsung bermaksud untuk mempengaruhi keobyektifan putusan peradilan. h. Asas Sidang Terbuka Untuk Umum Asas ini membawa konsekuensi bahwa semua putusan pengadilan hanya sah dan mempunyai kekuatan hukum apabila di ucapkan dalam siding terbuka untuk umum (pasal 17 dan pasal 18 UU 14/1970 jo pasal 70 UU PTUN) i. Asas Peradilan Berjenjang Jenjang peradilan di mulai dari tingkat yang paling bawah yaitu Pengadilan Tata Usaha Negara (tingkat pertama), kemudian Pengadilan Tinggi Tata Usaha Negara (banding), dan puncaknya (Kasasi) adalah Mahkamah Agung, dimungkinkan pula PK (MA). j. Asas Pembuktian Bebas. Hakimlah yang menetapkan beban pembuktian. Hal ini berbeda dengan ketentuan $1865 \mathrm{BW}$, seperti yang dijelaskan pada pasal 101, yang dibatasi dengan ketentuan Pasal 100. k. Asas para pihak harus didengar (audi et alteram partem) Asas para pihak harus didengar (audi et alteram partem) dan para pihak mempunyai kedudukan yang sama. 1. Asas peradilan dilakukan dengan sederhana, cepat, dan ringan Sebagaimana pasal 4 UU 14/1970, asas peradilan dilakukan dengan sederhana, cepat dan biaya ringan. Sederhana dalam hukum acara, cepat dalam waktu dan murah dalam biaya. $\mathrm{m}$. Asas putusan pengadilan mempunyai kekuatan mengikat (erga omnes)". Sengketa TUN adalah sengketa hukum publik. Dengan demikian putusan pengadilan berlaku bagi siapa saja-tidak hanya bagi para pihak yang bersengketa. $\mathrm{n}$. Asas pengadilan sebagai upaya terakhir untuk mendapatkan keadilan Asas pengadilan sebagai upaya terakhir (ultimum remidium)", sengketa administrasi sedapat mungkin diselesaikan melalui upaya administrasi (musyawarah mufakat), jika belum puas, maka ditempuh upaya peradilan (Pasal 48 UU PTUN) o. Asas Obyektivitas Untuk tercapainya putusan yang adil, maka hakim atau panitera wajib mengundurkan diri, apabila terikat hubungan keluarga sedarah atau semenda sampai derajat ketiga atau hubungan suami atau istri meskipun telah bercerai dengan tergugat, penggugat atau penasihat hukum atau antara hakim dengan salah seorang hakim atau panitera juga terdapat hubungan sebagaimana yang di sebutkan di atas, atau hakim atau panitera tersebut mempunyai kepentingan langsung dan tidak langsung dengan sengketanya, sebagaimana penjelasan pasal 78 dan pasal 79 UU PTUN. 


\section{PENUTUP}

Dengan dipaparkannya beberapa asas dalam melakukan peradilan tata usahan negara diharapkan dapat menjamin hak hak warga negara indonesia sebagai pihak yang akan melakukan acara dalam peradilan tata usaha negara. Dan dengan di jelaskannya asas asas dalam beracara peradilan tata usaha negara diharapkan tuntutan akan kewajiban pelaksana dan pihak pihak terkait dalam peradilan tata usaha negara dapat terkawal dengan ketat. Sebagai bagian materi kuliah hukum peradilan tata usaha negara dapat menjadi bagian materi yang dapat dimanfaatkan oleh akademisi sebagai bahan tambahan untuk menjadi referensi tambahan. Dengan dipaparkannya materi diatas diharapkan bermanfaat untuk pembaca dan terlebih kepada penulis sendiri sebagai bagian dari masyarakat hukum yang bernaung di bawah pancasila dan peraturan dibawahnya.

\section{DAFTAR PUSTAKA}

Darmini Roza dan Laurensius Arliman S, Peran Pemerintah Daerah Di Dalam Melindungi Hak Anak Di Indonesia, Masalah-Masalah Hukum, Volume 47, Nomor 1, 2018. https://doi.org/10.14710/mmh.47.1.2018.10-21

Laurensius Arliman S, Peranan Metodologi Penelitian Hukum di Dalam Perkembangan Ilmu Hukum di Indonesia, Soumatera Law Review, Volume 1, Nomor 1, 201. http://doi.org/10.22216/soumlaw.v1i1.3346.

Laurensius Arliman S, Peran Badan Permusyawaratan Desa di Dalam Pembangunan Desa dan Pengawasan Keuangan Desa, Padjadjaran Journal of Law, Volume 4, Nomor 3, 2017. https://doi.org/10.15408/jch.v4i2.3433.

Laurensius Arliman S, Penanaman Modal Asing Di Sumatera Barat Berdasarkan UndangUndang Nomor 25 Tahun 2007 Tentang Penanaman Modal, Supremasi Hukum, Volume 1, Nomor 1, 2018. http://dx.doi.org/10.36441/hukum.v1i01.102 .

Laurensius Arliman S, Memperkuat Kearifan Lokal Untuk Menangkal Intoleransi Umat Beragama Di Indonesia, Ensiklopedia of Journal, Volume 1, Nomor 1, 2018, https://doi.org/10.33559/eoj.v1i1.18.

Laurensius Arliman S, Perkawinan Antar Negara Di Indonesia Berdasarkan Hukum Perdata Internasional, Kertha Patrika, Volume 39, Nomor 3, 2017, https://doi.org/10.24843/KP.2017.v39.i03.p03.

Laurensius Arliman S, Partisipasi Masyarakat Di Dalam Pengelolaan Uang Desa Pasca Undang-Undang Nomor 6 Tahun 2014 Tentang Desa, Jurnal Arena Hukum, Volume 12, Nomor 2, 2019, https://doi.org/10.21776/ub.arenahukum.2019.01202.5.

Laurensius Arliman S, Mewujudkan Penegakan Hukum Yang Baik Di Negara Hukum Indonesia, Dialogica Jurnalica, Volume 11, Nomor 1, 2019, https://doi.org/10.28932/di.v11i1.1831.

Laurensius Arliman S, Mediasi Melalui Pendekatan Mufakat Sebagai Lembaga Alternatif Penyelesaian Sengketa Untuk Mendukung Pembangunan Ekonomi Nasional, UIR Law Review, Volume 2, Nomor 2, 2018, https://doi.org/10.25299/uirlrev.2018.vol2(02).1587

Laurensius Arliman S, Peranan Filsafat Hukum Dalam Perlindungan Hak Anak Yang Berkelanjutan Sebagai Bagian Dari Hak Asasi Manusia, Doctrinal, Volume 1, Nomor 2,2016.

Laurensius Arliman S, Ni Putu Eka Dewi, Protection of Children and Women's Rights in Indonesia through International Regulation Ratification, Journal of Innovation, Creativity and Change Volume 15, Nomor 6, 2021. 
Laurensius Arliman S, Gagalnya Perlindungan Anak Sebagai Salah Satu Bagian Dari Hak Asasi Manusia Oleh Orang Tua Ditinjau Dari Mazhab Utilitarianisme, Jurnal Yuridis, Volume 3, Nomor 2, 2016, http://dx.doi.org/10.35586/.v3i2.180.

Laurensius Arliman S, Tantangan Pendidikan Kewarganegaraan Pada Revolusi 4.0, Jurnal Ensiklopedia Sosial Review, Volume 2, Nomor 3, 2020.. 